\title{
Trade of electricity produced using renewable energy sources with the third countries
}

\author{
Alla Ljungman ${ }^{1}$, \\ Vidmantas Jankauskas ${ }^{2}$ \\ ${ }^{1}$ Inogate Project, \\ Khmelnitsky Str. 30/10, \\ Kyiv, Ukraine \\ E-mail:a.ljungman@inogate.org \\ ${ }^{2}$ Department of Building Energetics, \\ Vilnius Gediminas \\ Technical University, \\ Saulètekio Ave. 11, \\ LT-10223 Vilnius, Lithuania \\ E-mail:vidmantas.jankauskas@vgtu.lt
}

The article deals with the analysis of the requirements for the trade of electricity produced using renewable energy sources (RES) with the third countries. Georgia is considered a potential trade partner, as it has abundant hydro energy resources and plans for the interconnection with the neighbouring countries, first of all, with Turkey; and the latter is joining the continental European power system. The authors define what should be done in Georgia (technical, institutional, legal, regulatory developments) in order to fulfil the requirements of the Directive 2009/28/EC and allow electricity trade between the EU and Georgia.

Key words: renewable energy, electricity produced using renewable energy sources, renewable energy Directive, renewable energy targets, electricity trade with the third countries, Georgia's electricity sector

\section{INTRODUCTION}

The Renewable Energy Directive adopted in 2009 sets binding targets for renewable energy. The new Directive focuses on achieving a $20 \%$ share of renewable energy in the EU overall energy mix by 2020. Every Member State (MS) has to reach individual targets for the overall share of renewable energy in energy consumption. In addition, in the transport sector, all MS have to reach the same target of a $10 \%$ share of renewable energy [1]. All MS were obliged to prepare their National Renewable Energy Action Plans and submit them to the European Commission until June 30, 2010 [2].

To achieve so ambitious targets the EU Member States should cooperate between themselves. The convergence of support schemes and market integration has to be reinforced to ensure that renewable energy sources and technologies become economically competitive as soon as possible. The European Commission analysis suggests that up to 10 billion Euros could be saved yearly with a more inte- grated approach [3]. The Commission will assess the effective functioning of the cooperation mechanisms in 2014.

In order to meet its target on production of electricity from renewable energy sources, MS may cooperate with one or more third countries. Electricity produced using renewable energy sources in a third country can be counted towards the national target only if some strict conditions are met [1]. According to the MS forecasts that were submitted to the European Commission in December 2009, only a comparatively small quantity of energy is expected to be subject to the cooperation mechanisms. Most MS plan to fulfil their RES targets domestically, but they recognise the uncertainty of their projections at this stage. Therefore, it is worth to analyse potential of cooperation with some third countries in achieving the RES targets set by the Directive and detailed in the National Renewable Energy Action Plans.

The article summarises the requirements imposed by the Directive 2009/28/EC for the trade with the third coun- 
tries of electricity from renewable energy sources. As an example, it analyses the existing renewable energy framework in Georgia in order to assess what further measures would be necessary to meet the requirements of the new EU Directive, and provides some recommendations.

\section{MAIN PREREQUISITES OF THE DIRECTIVE ON RES}

The Directive 2009/28/EC replaces the Directives 2001/77/ EC and 2003/30/EC, and is enacted since January 2012. The EU Member States have completed the transposition of the new Directive into the national laws by December 2010. Under the new Directive, the requirements on Member States to promote the use of energy from renewable sources have been expanded and intensified by setting of mandatory targets.

The Directive 2009/28/EC essentially further harmonises the frameworks for the promotion of renewable energy across the EU Member States (MS) and for each MS sets binding overall targets for the share of energy from renewable sources in the gross final energy consumption in 2020. These targets are represented in Table 1 below.
Except the binding targets for each MS up to the year 2020, other main changes and amendments as opposed to the previous Directives include the following points:

1) The Directive now integrates the areas of renewable electricity - RES $e_{e}$ and bio-fuels that were previously treated separately. The scope has further been expanded to also include heating and cooling from renewable energy sources - RES $_{\text {th }}$.

2) The previous indicative targets for the share of renewable energy sources in electricity consumption, and bio-fuels and other renewable energy sources in transport have been adjusted and expanded to 2020. Most notably, these targets are now mandatory.

3) Cross-border cooperation among Member States and with third parties is explicitly encouraged in the Directive, through statistical transfers of RES, and the development of joint projects and joint support mechanisms.

In terms of reaching the mandatory national targets, the Renewable Energy Directive provides the flexibility to use support schemes and measures of cooperation between different EU-27 and with third countries in accordance with Articles 6-11 of the Directives that will help to fulfil their

Ta ble 1. National overall targets for the share of energy from renewable sources in gross final consumption of energy in 2020 [1]

\begin{tabular}{|c|c|c|}
\hline EU Member State & $\begin{array}{l}\text { Share of energy from renewable } \\
\text { sources in gross final consumption of energy, } \\
2005\left(S_{2005}\right)\end{array}$ & $\begin{array}{l}\text { Target for share of energy from renewable } \\
\text { sources in gross final consumption of energy, } \\
\qquad 2020\left(S_{2020}\right)\end{array}$ \\
\hline Belgium & $2.2 \%$ & $13 \%$ \\
\hline Bulgaria & $9.4 \%$ & $16 \%$ \\
\hline Czech Republic & $6.1 \%$ & $13 \%$ \\
\hline Denmark & $17.0 \%$ & $30 \%$ \\
\hline Germany & $5.8 \%$ & $18 \%$ \\
\hline Estonia & $18.0 \%$ & $25 \%$ \\
\hline Ireland & $3.1 \%$ & $16 \%$ \\
\hline Greece & $6.9 \%$ & $18 \%$ \\
\hline Spain & $8.7 \%$ & $20 \%$ \\
\hline France & $10.3 \%$ & $23 \%$ \\
\hline Italy & $5.2 \%$ & $17 \%$ \\
\hline Cyprus & $2.9 \%$ & $13 \%$ \\
\hline Latvia & $32.6 \%$ & $40 \%$ \\
\hline Lithuania & $15.0 \%$ & $23 \%$ \\
\hline Luxembourg & $0.9 \%$ & $11 \%$ \\
\hline Hungary & $4.3 \%$ & $13 \%$ \\
\hline Malta & $0.0 \%$ & $10 \%$ \\
\hline Netherlands & $2.4 \%$ & $14 \%$ \\
\hline Austria & $23.3 \%$ & $34 \%$ \\
\hline Poland & $7.2 \%$ & $15 \%$ \\
\hline Portugal & $20.5 \%$ & $31 \%$ \\
\hline Romania & $17.8 \%$ & $24 \%$ \\
\hline Slovenia & $16.0 \%$ & $25 \%$ \\
\hline Slovak Republic & $6.7 \%$ & $14 \%$ \\
\hline Finland & $28.5 \%$ & $38 \%$ \\
\hline Sweden & $39.8 \%$ & $49 \%$ \\
\hline United Kingdom & $1.3 \%$ & $15 \%$ \\
\hline
\end{tabular}


obligation by doing RES electricity generation projects in other MS or third countries:

1) Statistical transfers between MS (Article 6, Directive 2009/28/EC);

2) Joint projects between MS (Articles 7 and 8, Directive 2009/28/EC); $\mathrm{EC})$;

3) Joint support schemes (Article 11, Directive 2009/28/

4) Joint projects between MS and third countries, under the condition that RES electricity is imported to the EU (Articles 9 and 10, Directive 2009/28/EC).

The RES Directive also has provisions on guarantees of origin $(\mathrm{GoO})$ and set requirements to the MSs:

1) By 31 December 2012, Contracting Parties should set up a body that supervises the issuance, transfer and cancellation of guarantees of origin in accordance with the requirements of the Directive.

2) By 31 December 2012, Contracting Parties should set up a body that issues guarantees of origin on request by a producer of electricity from renewable energy sources and, if appropriate, in response to a request by producers of heating and cooling from renewable energy sources in accordance with the requirements of the Directive.

Recently, the first three cooperation mechanisms among the EU MS have been thoroughly analysed in [3]. The authors concluded that these three mechanisms had their specific benefits and disadvantages:

Statistical transfers between Member States can be applied easily, without the negotiation of a complex framework, but if applied solely (i. e. not as part of joint projects or joint support schemes), they tend to be an ad-hoc instrument that might not help developing additional RES potentials.

Joint projects provide the opportunity to develop additional RES potentials in Europe and allow an active involvement of private RES project developers, but pose the risk of complicating the European RES support conditions and interfering with national support instruments.

Joint support schemes could expose the prospects for the medium to long-term future - potentially leading the way to a more coordinated EU support framework, but they also need intensive debate and coordination between individual Member States. For this reason, long lead times for their practical implementation can be expected.

Cost effects of international trade in meeting the EU renewable energy target were shown earlier in [4]. One of the issues discussed in the EU is harmonisation of RES support schemes. Article [5] tries to answer the question which options for a possible future harmonisation of European RES-E support schemes exist, which barriers might prevent their implementation and which political, economic and legal consequences are attached to it. The EU Commission will review the success of the currently existing support schemes and the implementation of the flexibility measures of the Renewable Energy Directive for 2020.

This article analyses the problems and opportunities of RES electricity trade with the third countries.

\section{TRADE WITH THE THIRD COUNTRIES}

As it was mentioned above, the Directive 2009/28/EC sets binding national RES targets. Some MS would struggle to meet their mandatory targets, which do not correlate with the domestic RES potential or are too expensive to achieve. Klessmann [6] looks at the following three mechanisms: joint projects between MS, joint support schemes and statistical transfers between MS. She evaluates them against 4 sub-criteria: effectiveness, cost-effectiveness, political and technical criteria. The author concludes that the performance of flexibility mechanisms largely depends on design features that have not been defined yet. The researcher also points out that the principle weakness of the joint project mechanism is that it is "negotiated from case-to-case, which could lead to complicated agreements and increased complexity of RES support in Europe". Further we will consider only Article 9 which sets requirements for joint projects between MS and third countries. Up to now, trade with the third country flexibility mechanism has not been studied systematically.

In order to meet MS target on production of electricity from renewable energy sources, one or more Member States may cooperate with one or more third countries. The RES electricity produced in a third country can be counted towards the national target only if the following conditions are met:

1) Electricity is consumed within the Community, and an equivalent amount of electricity is nominated to the interconnection capacity and registered in the schedule of balance by transmission system operators (Article $9.2(\mathrm{a})$ );

2) Electricity is produced by newly constructed or refurbished installation (Article 9.2 (b));

3) Electricity produced has not received support from the support scheme of a third country other than investment aid granted to installation (Article 9.2 (c)).

MS may apply to the Commission to include into national targets an amount of electricity from RES produced and consumed in a third country in the context of the construction of an interconnector between MS and the third country if:

1) Construction was started by 31 December 2016 - Article $9.3(\mathrm{a})$;

2) It is not possible for the interconnector to become operational by 31 December 2020 - Article 9.3 (b);

3) It is possible for the interconnector to become operational by 31 December 2022 - Article 9.3 (c); 
4) Interconnector is to be used for export of RES to the Community - Article 9.3 (d);

5) Interconnector is to be used for joint project producing energy from RES - Article 9.3 (e).

MS has to notify the Commission of the amount of electricity produced in a third country to count towards MS national targets - Article 9.4. Notification is to include:

1) Description of proposed installation - Article $9.5(\mathrm{a})$;

2) Amount of electricity to be counted towards the MS national target - Article 9.5 (b);

3) Period during which electricity is to count towards the MS national target - Article 9.5 (c);

4) Amount of electricity from installation to be used by a third country - Article 9.5 (d).

The period specified in the notification is not to extend beyond 2020 - Article 9.6.

According to the MS forecasts that were submitted to the European Commission in December 2009, only a comparatively small quantity of energy is expected to be subject to the cooperation mechanisms: only five Member States expect to have a deficit of in total 2 Mtoe in 2020, less than $1 \%$ of the total renewable energy needed in 2020; ten Member States expect to have a surplus of in total 5.5 Mtoe in 2020, around $2 \%$ of the total renewable energy needed in 2020. The National Renewable Energy Action Plans (NREAP) submitted by the MSs to the European Commission by 30 June 2010 specify how each MS expects to reach its legally binding 2020 target for the share of renewable energy in their final energy consumption.

\section{THE NATIONAL RENEWABLE ENERGY ACTION PLANS}

The NREAPs were prepared in accordance with the template published by the Commission [7]. The NREAP provides detailed roadmaps of how each MS expects to reach its legally binding target. From the NREAPs one may see how MSs are planning to utilise cooperative mechanisms, especially under provisions of Article 9, Directive 2009/28/ EC. Specifically in Chapter 4.7 of the NREAP, each MS indicates the use of statistical transfers between MSs and planned participation in joint projects with other Member States and third countries.
Most MSs plan to fulfil their RES targets domestically, but they recognise the uncertainty of their projections at this stage. Italy and Luxembourg plan to use joint projects and / or statistical transfers for target achievement. Sweden plans a joint support scheme with Norway. Only Italy shows a special interest in joint projects with third countries, and Table 2 summarises the forecast for quantities of renewable electricity which could be imported annually following the completion of the planned interconnection infrastructure.

Practically all NREAPs fail to present national procedural aspects to arrange statistical transfers or joint projects, including assigning of designated bodies and focal points.

\section{TECHNICAL REQUIREMENTS FOR A JOINT PROJECT WITH THIRD COUNTRIES}

As it was mentioned above, Article 9 of the RES Directive puts forward certain requirements for the MS and the third country hosting a joint project. For the purposes of measuring the target compliance with the requirements of this Directive concerning national overall targets, the amount of electricity produced from renewable energy sources in the third country is consumed in the Community and the following requirements are met:

- $\quad$ an equivalent amount of electricity to the electricity accounted for has been firmly nominated to the allocated interconnection capacity by all responsible transmission system operators in the country of origin, the country of destination and, if relevant, each third country of transit;

- an equivalent amount of electricity to the electricity accounted for has been firmly registered in the schedule of balance by the responsible transmission system operator on the Community side of an interconnector; and

- the nominated capacity and the production of electricity from renewable energy sources by the installation refer to the same period of time;

- $\quad$ the electricity is produced by a newly constructed installation that became operational after 25 June 2009 or by the increased capacity of an installation that was refurbished after that date under a joint project; and

- $\quad$ the amount of electricity produced and exported has not received support from the support scheme of a third country other than investment aid granted to the installation.

Table 2. NREAP of Italy: imports of RES from the third countries [8]

\begin{tabular}{|c|c|c|c|}
\hline Third country & Start of import & TWh from RES / year & Mtoe from RES / year \\
\hline Switzerland & * & 4 & 0.344 \\
\hline $\begin{array}{c}\text { Montenegro and Balkan states connected } \\
\text { to the Montenegrin network }\end{array}$ & 2016 & 6 & 0.516 \\
\hline Albania & 2016 & 3 & 0.258 \\
\hline Tunisia & 2018 & 0.6 & 0.052 \\
\hline
\end{tabular}




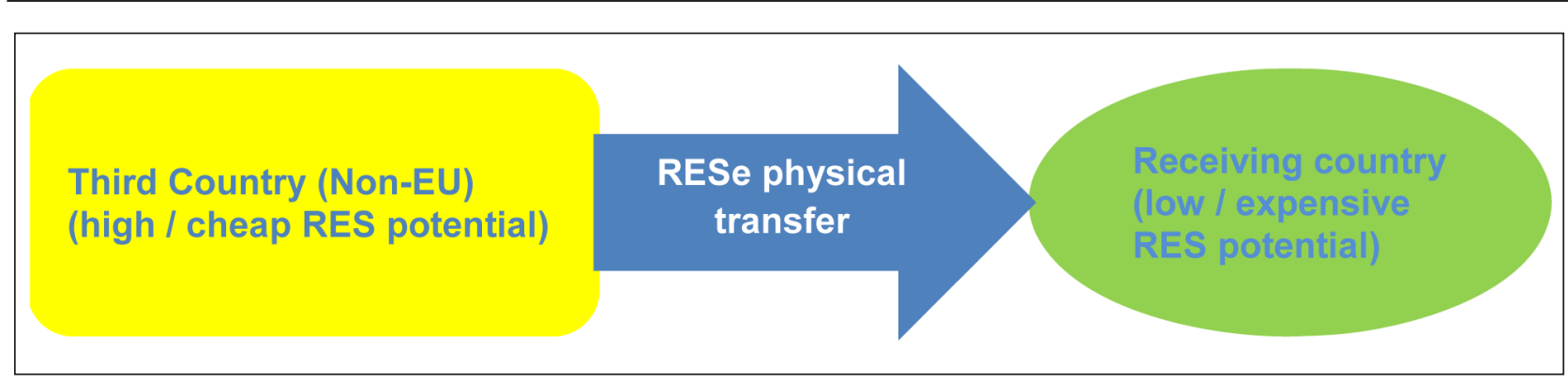

Figure. RES transfer from a third country to the EU Member States

So the physical transfer of the electricity produced from renewables in a third country should be physically transferred and consumed in the EU as it is presented in the Figure below.

If currently there is no interconnection between a third country and the EU, there is still a possibility to realise a joint project in the context of the construction of an interconnector with a very long lead-time between a Member State and a third country if the following conditions are met:

Construction of the interconnector was started by 31 December 2016;

It is not possible for the interconnector to become operational by 31 December 2020;

It is possible for the interconnector to become operational by 31 December 2022;

After it becomes operational, the interconnector will be used for the export to the Community of electricity generated from renewable energy sources;

The application relates to a joint project that fulfils the criteria described above and that will use the interconnector after it becomes operational, and to a quantity of electricity that is no greater than the quantity that will be exported to the Community after the interconnector becomes operational.

The proportion or amount of electricity produced by any installation in the territory of a third country, which is to be regarded as counting towards the national overall target of one or more Member States for the purposes of measuring compliance with Article 3 of the Directive 2009/28/ $\mathrm{EC}$, shall be notified to the Commission. When more than one MS is concerned, the distribution between MS of this proportion or amount shall be notified to the Commission. This proportion or amount shall not exceed the proportion or amount actually exported to and consumed in the Community. The notification shall be made by each MS towards whose overall national target the proportion or amount of electricity is to count. The notification shall:

describe the proposed installation or identify the refurbished installation;

specify the proportion or amount of electricity produced from the installation which is to be regarded as counting towards the national target of MS as well as, subject to confidentiality requirements, the corresponding financial arrangements;

specify the period, in whole calendar years, during which the electricity is to be regarded as counting towards the national overall target of the MS; and

include a written acknowledgement of 2 conditions mentioned above by the third country in whose territory the installation is to become operational and the proportion or amount of electricity produced by the installation which will be used domestically by that third country.

The period specified shall not extend beyond 2020 . The duration of a joint project may extend beyond 2020 . A notification made under this Article may not be varied or withdrawn without the joint agreement of the Member State making the notification and the third country that has acknowledged the joint project accordingly.

\section{CASE STUDY: TECHNICAL POSSIBILITIES FOR ELECTRICITY TRANSMISSION FROM GEORGIA TO THE EU}

Georgia's electricity grid is connected with the neighbouring countries through the following lines:

$330 \mathrm{kV}$ line to Azerbaijan operated by Sakrusenergo;

$220 \mathrm{kV}$ line to Armenia operated by the Georgian State Electric System (GSE);

$500 \mathrm{kV}$ line to Russia operated by Sakrusenergo;

$220 \mathrm{kV}$ line via Abkhazia to Russia operated by GSE; and

$220 \mathrm{kV}$ line operating in the island mode to Turkey operated by Sakrusenergo.

GSE acting as a transmission system operator has announced the following expansion of the system:

1) Construction of new $500 \mathrm{kV}$ substations and interconnections to Azerbaijan. The line should become operational in January-February 2012;

2) Construction of new $400 \mathrm{kV}$ substations and interconnections to Turkey that should be finished by January 2013;

3) Construction of new $400 \mathrm{kV}$ substations and interconnections to Armenia that will be operational in 2015 . 
The electricity distribution company Energo-Pro is also building a $154 \mathrm{kV}$ interconnection to Turkey that should be ready by 2013-2014. The future plans for the development of interconnection capacities are shown in Table 3.

Currently, the RESe generation in Georgia has no state incentives. The State Programme "Renewable Energy 2008" provides support to investors only [10]. There is a lot of information on potential small hydro power projects available on the internet portal of the Ministry of Energy and Natural Resources.

Physical transfer of RES via Turkey seems possible even now, though an additional study with a high level of details on the transit conditions via Turkey will be required.

The programme "Renewable Energy 2008" sets some limitation for RES generators to sell electricity to the third parties. The Programme requires the power plants, in the winter season of each year during three months agreed by the memorandum, the electricity produced by them to be sold to the market operator (ESCO) to cover the domestic demand.

Further assessment of the available potential for the development of renewable energy sources in Georgia using methodologies (template of NREAP) adopted under Directive 2009/28/EC is suggested as a first step. Such an assessment will be a good basis to approach the EU Member States with the high commitment to develop joint projects under Article 9 of the EU RES Directive.

Secondly, it is recommended that the Ministry of Energy and Natural Resources of Georgia should designate a body (e. g. council represented by specialists from the Ministry of Energy, Georgian National Energy and Water Regulatory Commission - GNEWRC, GSE, ESCO) with the responsibilities to:

approach designated authorities in the EU Member States with stringent commitments to implement joint projects under Article 9 of the Directive;

approve notification to the EC and EU Member State designated authority under Article 9 of the Directive.
Further, the Ministry of Energy and Natural Resources of Georgia should carry out an overview of national rules concerning the certification, licensing and connection procedures that are applied to power plants and associated transmission and distribution network infrastructures for the production of electricity from renewable energy sources and make sure that:

the respective responsible national, regional and local administrative bodies for certification, licensing and connection procedures including spatial planning are clearly coordinated and defined, with transparent timetables for determining planning and building applications;

comprehensive information on the processing of certification, licensing and connection applications for renewable energy installations and on available assistance to applicants is made available;

rules governing certification, licensing and connection are objective, transparent, proportionate, do not discriminate between applicants and take fully into account the particularities of individual renewable energy technologies;

administrative charges paid by consumers, planners, architects, builders, equipment and system installers and suppliers are transparent and cost-related.

Transmission system operators and distribution system operators should provide any new producer of energy from renewable sources wishing to be connected to the system with the comprehensive and necessary information required, including:

a comprehensive and detailed estimate of the costs associated with the connection;

a reasonable and precise timetable for receiving and processing the request for grid connection.

GNEWRC should ensure that the charging of transmission and distribution tariffs does not discriminate against electricity from renewable energy sources, including in particular electricity from renewable energy sources produced in peripheral regions, such as island regions, and in regions of low population density. The Ministry of Energy and Natural Resources should also revise the requirement

Table 3. Existing interconnection capacities and plans of development [9]

\begin{tabular}{|c|c|c|c|c|}
\hline \multirow{2}{*}{ Voltage, kV } & \multirow{2}{*}{ Route } & \multicolumn{3}{|c|}{ Export capacity, MW } \\
\hline & & 2010 & 2015 & 2020 \\
\hline \multirow[t]{2}{*}{500} & Russia-Georgia (North-West) & 600 & 600 & 600 \\
\hline & Georgia-Azerbaijan & & 600 & 600 \\
\hline \multirow[t]{2}{*}{400} & Georgia-Turkey & & 700 & 1050 \\
\hline & Georgia-Armenia & & & 600 \\
\hline 330 & Georgia-Azerbaijan (East) & 160 & 250 & 250 \\
\hline \multirow[t]{3}{*}{220} & Georgia-Georgia (North-West) & 100 & 100 & 100 \\
\hline & Georgia-Turkey (South-West) & 160 & 160 & 160 \\
\hline & Georgia-Armenia (South-East) & 160 & 160 & 160 \\
\hline \multirow[t]{2}{*}{110} & Russia-Georgia & $60+60$ & $60+60$ & $60+60$ \\
\hline & Armenia-Georgia & $50+40$ & $50+40$ & $50+40$ \\
\hline
\end{tabular}


set by the "Renewable Energy 2008" Programme. The conditions of electricity transition through Turkey should be studied in details.

\section{CONCLUSIONS}

1. In order to meet its target on production of electricity from renewable energy sources set by the RES Directive, EU Member State may cooperate with other Member States and also with third countries. Electricity produced using renewable energy sources in a third country can be counted towards the national target if some strict conditions are met.

2. As a potential country for cooperation with the $\mathrm{EU}$ in RESe trade is Georgia. Georgia has a huge available potential for the development of renewable energy sources as well as technical possibilities (existing and planned) for cooperation with the EU Member States. Assessment of the potential using methodologies adopted under Directive 2009/28/ EC will be a good basis to approach the EU Member States with the high commitment to develop joint projects under Article 9 of the EU RES Directive.

3. The Ministry of Energy and Natural Resources of Georgia should carry out an overview of national rules concerning the certification, licensing and connection procedures that are applied to power plants and associated transmission and distribution network infrastructures for the production of electricity from renewable energy sources in order to harmonise them with the $\mathrm{EU}$ ones.

Received 5 January 2012 Accepted 2 March 2012

\section{References}

1. Directive 2009/28/EC of the European Parliament and of the Council of 23 April 2009 on the promotion of the use of energy from renewable sources and amending and subsequently repealing Directives 2001/77/EC and 2003/30/EC. Official Journal L 140. 0506 2009. P. 00160062.

2. Template for the National Renewable Energy Action Plans. Official Journal L 182. 1507 2009. P. 00330062.

3. Klessmann C., Lamers P., Ragwitz M., Resch G. Design options for cooperation mechanisms under the new European renewable energy directive. Energy Policy. 2010. Vol. 38. P. 4679-4691.

4. Voogt M. H., Uyterlinde M. A. Cost effects of international trade in meeting EU renewable electricity targets. Energy Policy. 2006. Vol. 34. No. 3. P. 352-364.

5. Bergmann J., Bitsch Ch., Behlau V., Jensen S., Held A., Pfluger B., Ragwitz M., Resch G. A European harmonised policy to promote RES-electricity-sharing costs \& benefits. A report compiled within European research project Futures-e. December 2008.

6. Klessmann C. The evolution of flexibility mechanisms for achieving European renewable energy targets 2020ex-ante evaluation of the principle mechanisms. Energy Policy. 2009. Vol. 37. P. 4966-4979.

7. Italian National Renewable Energy Action Plan. Italian Ministry for Economic Development. http://ec.europa. eu/energy/renewables/transparency_platform/doc/ national_renewable_energy_action_plan_italy_en.pdf

8. Renewable Energy Targets: Commission calls on Member States to boost cooperation. Press Release IP/11/113. Brussels, 31 January 2011.

9. Georgian State Electricity System. Annual Report 2010.

10. State Programme "Renewable Energy 2008". Ministry of Energy and Natural Resources, Republic of Georgia. www.minenergy.gov.ge

\section{Alla Ljungman, Vidmantas Jankauskas}

\section{PREKYBA SU TREČIOSIOMIS ŠALIMIS ELEKTRA, PAGAMINTA NAUDOJANT ATSINAUJINANČIUS ENERGIJOS IŠTEKLIUS}

\section{Santrauka}

Straipsnyje aptariami Europos Sąjungos direktyvos 2009/28/EB reikalavimai prekybai elektra, pagaminta naudojant atsinaujinančius energijos išteklius, su trečiosiomis šalimis siekiant, kad iš trečiosios šalies nupirktas elektros kiekis būtų i̊skaitytas ị ES šaliai narei nustatytas kvotas. Būtina, kad ne tik trečiojoje šalyje pagaminta elektra nebūtų remiama toje šalyje, tačiau ir kad elektrinè būtų nauja (pastatyta po 2009 metų), kad būtų techninès galimybės fiziškai perduoti ten pagamintą elektrą, t. y. veikiančios ar naujai statomos pakankamo pralaidumo jungtys, o taip pat nustatytos šių jungčių panaudojimo taisyklès.

Straipsnyje nagrinejjamas konkretus pavyzdys - galimybė ES šalims prekiauti elektra su Gruzija, pagaminta naudojant atsinaujinančius energijos išteklius. Gruzija turi didžiulị hidroenergijos potencialą, ji stato ir planuoja statyti daug naujų hidroelektrinių bei jų kaskadų, taip pat jungtis su kaimyninėmis šalimis, visų pirma, su Turkija. Kadangi Turkija sujungta su kontinentine Europos elektros sistema (ENTSO-E), tai techniškai Gruzija gali tiekti elektrą Europai, reikia tik nustatyti jungčių panaudojimo ir valdymo taisykles, taip pat suderinti Gruzijos teisines, reguliavimo ir valdymo normas su ES direktyvos reikalavimais.

Raktažodžiai: atsinaujinanti energetika, ES direktyva apie atsinaujinančią energetiką, ES šalių narių uždaviniai atsinaujinančiai energetikai, prekyba elektra su trečiosiomis šalimis, pagaminta naudojant atsinaujinančius energijos išteklius, Gruzijos elektros energetika 
Алла Люнгман, Видмантас Янкаускас

\section{ТОРГОВЛЯ С ТРЕТЬИМИ СТРАНАМИ \\ ЭЛЕКТРОЭНЕРГИЕЙ, ПРОИЗВЕДЕННОЙ \\ ИСПОЛЬЗУЯ ВОЗОБНОВЛЯЕМЫЕ ИСТОЧНИКИ ЭНЕРГИИ}

\section{Резюме}

В статье обсуждаются требования директивы Европейского Союза 2009/28/EC по торговле электроэнергией, произведенной используя возобновляемые источники энергии, с третьими странами, с целью учета этого объема энергии в квотах, установленных для каждой страны-члена ЕС. Требуется, чтобы в третьих странах эта энергия не получала поддержки, чтобы электростанция была новая (построена после 2009 г.), а также чтобы существовали технические возможности передачи этой энергии в EC, т. е. чтобы существовали или строились соединительные линии, чтобы были достаточные пропускные мощности на границе (границах), а также установлены правила использования этих линий.
В статье анализируется конкретный пример - возможность торговать странам-членам ЕС электроэнергией, полученной используя возобновляемые источники энергии, с Грузией. В Грузии иммется огромный потенциал гидроэнергии, она строит и планирует строительство новых гидростанций и их каскадов, а также соединительных линий с соседями, прежде всего, с Турцией. Так, как турецкая электроэнергетическая система соединена с континентальной европейской системой (ENTSO-E), то технически Грузия может поставлять электроэнергию в ЕС, необходимо только установить правила пользования соединительных линий и согласовать соответствующие грузинские юридические и нормативные документы с требованиями директивы ЕС.

Ключевые слова: возобновляемая энергетика, директива EC по возобновляемой энергетике, задачи стран-членов ЕС по возобновляемой энергетике, торговля электроэнергией, произведенной используя возобновляемые источники энергии, с третьими странами, электроэнергетика Грузии 